\title{
MANAJEMEN PENDIDIKAN DALAM KEBIJAKAN EKSTRAKURIKULER DI SEKOLAH DAN MADRASAH
}

\author{
Ayep Rosidi \\ Email: rosidi.ayep@gmail.com \\ Universitas Darul Ulum Islamic Centre Sudirman (UNDARIS) \\ Jalan Tentara Pelajar No. 13 Ungaran. Semarang. 50514
}

\begin{abstract}
ABSTRAK
Penelitian ini menggunakan penelitian kualitatif dengan jenis fenomenologis, yaitu memiliki tiga tahap: intuiting, analyzing, dan describing. Deskripsi tulisan ini bertujuan untuk mengkomunikasikan arti dan makna persepsi dan kebutuhan pendidikan tentang pandangan kebijakan ekstrakulikuler dari nforman. Penliti mengidentifikasi fenomena berupa kegiatan-kegiatan kebijakan ekstrakurikuler yang terjadi di sekolah dan Madrasah. Alasan penelitian menggunakan metode kualitatif agar peneliti dapat mengungkap informansi tentang kebijakan kegiatan ekstra kurikuler yang diterapkan sesuai peraturan Undang-Undang No 20 Tahun 2003 tentang sistem pendidikan nasional dan Merujuk pada Peraturan Menteri Pendidikan dan Kebudayaan Republik Indonesia Nomor 62 tahun 2014 tentang Kegiatan Ekstrakurikuler pada Pendidikan Dasar dan Pendidikan Menengah.
\end{abstract}

Kata kunci: manajemen pendidikan, kebijakan ekstrakulikuler

\section{ABSTRACT}

This study uses a qualitative research with a phenomenological type, which has three stages: intuitive, analyzing, and describing. The description of this paper aims to communicate the meaning and significance of perceptions and educational needs about the extracurricular policy views of the informants. Researchers identify phenomena in the form of extracurricular policy activities that occur in schools and Madrasahs. The reason for using qualitative methods is so that researchers can reveal information about policies on extracurricular activities that are implemented according to Law No. 20 of 2003 concerning the national education system and Referring to the Regulation of the Minister of Education and Culture of the Republic of Indonesia No. 62 of 2014 concerning Extracurricular Activities in Basic Education and Secondary Education.

Keywords: education management, extracurricular policy 


\section{PENDAHULUAN}

Sekolah merupakan lembaga pendidikan yang menampung peserta didik dan dibina agar mereka memiliki kemampuan, kecerdasan dan keterampilan. Hal ini sesuai dengan UndangUndang Nomor 20 Tahun 2003 tentang Sistem Pendidikan Nasional Pasal 3 yang menyebutkan bahwa pendidikan nasional bertujuan untuk berkembangnya potensi peserta didik agar menjadi manusia yang beriman dan bertakwa kepada Tuhan Yang Maha Esa, berakhlak mulia, sehat, berilmu, cakap, kreatif, mandiri, dan menjadi warga negara yang demokratis serta bertanggung jawab.

Untuk mencapai tujuan pendidikan nasional tersebut, dalam proses pendidikan diperlukan pembinaan secara terkoordinasi dan terarah, sehingga peserta didik diharapkan dapat mencapai prestasi belajar yang maksimal. Untuk memenuhi hal tersebut peserta didik harus mempunyai minat dan motivasi agar bisa mencapai prestasi belajar yang diharapkan tersebut.

Minat merupakan suatu ketertarikan yang dimiliki individu atas dasar rasa senang. Jadi orang yang senang terhadap suatu obyek akan dapat menggerakan dirinya untuk menentukan suatu pilihan yang diminatinya. Seperti yang dijelaskan oleh Suryabrata (1988:109) bahwa minat sebagai kecenderungan dalam diri individu untuk tertarik pada suatu objek atau menyenangi suatu obyek. Timbulnya minat terhadap suatu obyek ini ditandai dengan adanya rasa senang atau tetarik. Jadi boleh dikatakan orang yang berminat terhadap sesuatu maka seseorang tersebut akan merasa senang atau tertarik terhadap obyek yang diminati tersebut.

Minat dan motivasi peserta didik yang kuat akan meningkatkan kemauan dan semangat yang tinggi dalam belajar, karena antara minat dan motivasi semangat belajar mempunyai hubungan yang erat, sebagaimana yang dikatakan oleh Sardiman, A.M. (2001:78) bahwa dalam kegiatan belajar, maka motivasi menimbulkan kegiatan belajar, menjamin kelangsungan dari kegiatan belajar, sehingga tujuan yang dikehendaki oleh subjek belajar itu dapat tercapai.

Motivasi sangat berperan dalam belajar, dengan motivasi inilah peserta didik menjadi tekun dalam proses belajar mengajar, dan dengan motivasi itu pula kualitas hasil belajar peserta didik dapat diwujudkan dengan baik. Peserta didik yang dalam proses belajar mempunyai motivasi yang kuat dan jelas akan tekun dan berhasil dalam belajarnya, tingginya motivasi dalam belajar berhubungan dengan tingginya prestasi belajar.

Dalam hal ini sekolah perlu menyediakan wadah atau program yang bisa menyalurkan bakat dan minat peserta didik, agar peserta didik bisa termotivasi dalam belajar dan diluar pelajaran sekolah peserta didik dapat meningkatkan kemampuan dan keterampilannya, sehingga peserta didik bisa menggali lebih banyak lagi potensi yang ada dalam dirinya.

Salah satu wadah yang menjadi pembinaan peserta didik di sekolah adalah kegiatan ekstrakurikuler. Kegiatan-kegiatan yang diadakan dalam program ekstrakurikuler didasari atas tujuan dari pada kurikulum sekolah. Melalui kegiatan ekstrakurikuler yang beragam peserta didik dapat mengembangkan bakat, minat dan kemampuannya.

Kegiaatan ekstrakurikuler atau yang sering disingkat (Ekskul) ini merupakan suatu kegiatan belajar peserta didik di luar sekolah yang sangat potensial untuk menciptakan peserta didik yang kreatif, berinovasi, trampil, dan berprestasi. Kegiatan ini sungguh sangat berharga bagi perkembangan pribadi anak, utamanya dalam mengasa ketrampilan yang dimiliki anak tersebut.

\section{METODE PENELITIAN}

Penelitian ini menggunakan penelitian kualitatif dengan jenis fenomenologis. Fenomenologis merupakan strategi penelitian di mana di dalamnya peneliti mengidentifikasi hakikat pengalaman manusia tentang suatu fenomena tertentu. Proses penelitian kualitatif dengan jenis fenomenologis mempunyai 3 tahap, yaitu intuiting, analyzing, dan describing. Tahap intuiting, peneliti memasuki secara total dengan empati dan menghargai ungkapan informasi pada fenomena yang diteliti dan merupakan proses dimana peneliti mulai tahu tentang fenomena yang digambarkan oleh informan. Peneliti bersifat alami tanpa mempengaruhi informan. Tahap analyzing peneliti mengidentifikasi intisari tentang fenomena berdasarkan data-data yang diperoleh dari informan. Pada tahap ini peneliti mengadakan identifikasi secermat mungkin untuk memperoleh keakuratan dan kemurnian hasil sesuai dengan pengalaman informan. Tahap describing, peneliti membuat narasi yang luas dan mendalam tentang fenomena yang diteliti. Deskripsi tulisan ini bertujuan untuk mengkomunikasikan arti dan makna persepsi dan kebutuhan spiritual sesuai pandangan informan. Penliti mengidentifikasi fenomena berupa kegiatan-kegiatan kebijakan ekstrakurikuler yang 
terjadi di sekolah dan Madrasah. Alasan penelitian menggunakan metode kualitatif agar peneliti dapat mengungkap informansi tentang kebijakan kegiatan ekstra kurikuler yang diterapkan sesuai peraturan Undang-Undang No 20 Tahun 2003 tentang sistem pendidikan nasional.

\section{PEMBAHASAN DAN HASIL}

\section{Ektrsa Kurikuler Di Sekolah/Madrasah}

\section{Pengertian Ekstrakurikuler}

Undang-Undang Nomor 20 Tahun 2003 tentang Sistem Pendidikan Nasional Pasal 3 menyebutkan bahwa pendidikan nasional bertujuan untuk berkembangnya potensi peserta didik agar menjadi manusia yang beriman dan bertakwa kepada Tuhan Yang Maha Esa, berakhlak mulia, sehat, berilmu, cakap, kreatif, mandiri, dan menjadi warga negara yang demokratis serta bertanggung jawab. Untuk mencapai tujuan pendidikan nasional di atas dapat dilakukan melalui intrakurikuler dan ekstrakurikuler.

Merujuk pada Peraturan Menteri Pendidikan dan Kebudayaan Republik Indonesia Nomor 62 tahun 2014 tentang Kegiatan Ekstrakurikuler pada Pendidikan Dasar dan Pendidikan Menengah, ekstrakurikuler adalah kegiatan pengembangan karakter dalam rangka perluasan potensi, bakat, minat, kemampuan, kepribadian, kerja sama, dan kemandirian peserta didik secara optimal yang dilakukan di luar jam belajar kegiatan intrakurikuler dan kegiatan kokurikuler di bawah bimbingan dan pengawasan satuan pendidikan.

Ekstrakurikuler adalah kegiatan pendidikan di luar mata pelajaran dan pelayanan konseling untuk membantu pengembangan peserta didik sesuai dengan kebutuhan, potensi, bakat dan minat melalui kegiatan yang secara khusus diselenggarakan oleh pendidik dan atau tenaga kependidikan yang berkemampuan dan berkewenangan di sekolah atau madrasah (Muhaimin dkk, 2009: 74). Berdasarkan definisi tersebut, maka kegiatan di sekolah ataupun di luar sekolah yang terkait dengan tugas belajar suatu mata pelajaran bukanlah kegiatan ekstrakurikuler.

Ekstra kurikuler yang diselenggarakan di satuan pendidikan terdiri dari ekstra kurikuler wajib dan ekstra kurikuler pilihan. Kegiatan ekstrakurikuler Wajib sebagaimana dimaksud merupakan kegiatan ekstrakurikuler yang wajib diselenggarakan oleh satuan pendidikan dan wajib diikuti oleh seluruh peserta didik yaitu pendidikan kepramukaan. Kegiatan ekstrakurikuler pilihan merupakan kegiatan ekstrakurikuler yang dikembangkan dan diselenggarakan oleh satuan pendidikan sesuai bakat dan minat peserta didik. Ekstra kurikuler ini bisa berbentuk latihan olah-bakat dan latihan olah-minat.

Kegiatan Ekstrakurikuler diselenggarakan dengan tujuan untuk mengembangkan potensi, bakat, minat, kemampuan, kepribadian, kerjasama, dan kemandirian peserta didik secara optimal dalam rangka mendukung pencapaian tujuan pendidikan nasional.

2. Fungsi ekstra kurikuler

Ektrakurikuler memiliki fungsi yang bisa berdampak pada peserta didik. Fungsifungsi tersebut adalah sebagai berikut:

a. Pengembangan, yaitu sebagai wahana pengembangan minat dan bakat peserta didik.

b. Sosial, yaitu sebagai wahana untuk memperluas pengalaman bersosialisasi, praktik keterampilan berkomunikasi, dan internalisasi nilai-nilai karakter.

c. Rekreatif, yaitu dilakukan dalam suasana gembira dan menyenangkan, sehingga suasana ini menunjang proses perkembangan potensi /kemampuan personal peserta didik.

d. Persiapan Karir, yaitu sebagai wahana memfasilitasi persiapan peserta didik melalui pengembangan bakat dan minat dalam bidang ekstrakurikuler yang diminati.

3. Bentuk ekstrakurikuler

Sebagaimana diatur dalam

Permendikbud RI Nomor 62 tahun 2014 tentang Kegiatan Ekstrakurikuler Pada Pendidikan Dasar dan Pendidikan Menengah, bentuk kegiatan ekstrakurikuler dapat berupa:

a. Krida, misalnya: Kepramukaan, Latihan Kepemimpinan Peserta didik (LKS), Palang Merah Remaja (PMR), Usaha Kesehatan Sekolah (UKS), Pasukan Pengibar Bendera (Paskibra), dan lainnya;

b. Karya ilmiah, misalnya: Kegiatan Ilmiah Remaja (KIR), kegiatan penguasaan keilmuan dan kemampuan akademik, penelitian, dan lainnya;

c. Latihan olah-bakat dan olah-minat, misalnya: pengembangan bakat olahraga, seni dan budaya, pecinta alam, jurnalistik, teater, teknologi informasi dan komunikasi, rekayasa, dan lainnya; 
d. Keagamaan, misalnya: tahfiz qur'an, baca tulis alqur'an, marawis, retreat;

e. Bidang pengembangan lainnya, yang disesuaikan dengan prioritas dan analisis potensi dan minat peserta didik di sekolah.

Dari sekian bentuk ekstra kurikuler, sekolah perlu menentukan pilihan prioritas kegiatan ekstrakurikuler yang akan diselenggarakan berdasarkan analisis potensi dan minat peserta didik, serta kemampuan sekolah dalam memenuhi sumberdaya yang dibutuhkan dalam penyelenggaraan kegiatan ekstrakurikuler. Dengan demikian variasi kegiatan ekstrakurikuler yang ada pada setiap sekolah beragam sesuai dengan kondisi, sarana dan prasarana yang ada di sekolah tersebut.

4. Implementasi Ekstrakurikuler di sekolah/madrasah

Dalam implementasi di lapangan, ekstrakurikuler di sekolah/madrasah setidaknya meliputi perencanaan, pelaksanaan, pengawasan dan evaluasi. Hal ini berdasarkan Peraturan Pemerintah no 32 tahun 2013 tentang perubahan atas Peraturan Pemerintah nomor 19 Tahun 2005 tentang Standar Nasional Pendidikan bahwa kegiatan ekstrakurikuler termasuk di dalam rencana kerja tahunan satuan pendidikan, dan kegiatan ekstrakurikuler perlu dievaluasi pelaksanaannya setiap semester oleh satuan pendidikan.

Pada

tahap

perencanaan

ekstrakurikuler, dilakukan dengan melakukan analisis terhadap potensi dan minat peserta didik dan kemampuan sekolah/madrasah dari aspek sumberdaya yang dibutuhkan terlebih dahulu. Dari hasil analisis itu, sekolah/madrasah kemudian menentukan ekstrakurikuler apa saja yang bisa diberikan kepada peserta didik selama satu tahun ajaran berjalan.

Pada tahap pelaksanaan, kegiatan ekstrakurikuler antara satu sekolah dengan yang lain bisa berbeda. Kegiatan ekstrakurikuler sebagai upaya untuk menumbuhkan bakat minat peserta didik dilakukan dengan penuh tanggung jawab baik dari kepala sekolah, guru dan masing-masing penanggung jawab kegiatan. Dalam hal ini pembina/pelatih kegiatan ekstrakurikuler memegang peranan penting untuk menjadi pelaksanaan kegiatan. Karena, pelatih berperan untuk membimbing dan membina peserta didik selama kegiatan berlangsung, sehingga tumbuh kembangnya peserta didik dapat digambarkan jelas oleh pelatih kegiatan

Agar kegiatan ekstra kurikuler ini bisa berjalan dengan efektif dan efisien, diperlukan kerjasama yang sinergis dengan beberapa pihak. Beberapa pihak yang terlibat dalam pelaksanaan ekstra kurikuler di sekolah/madrasah antara lain:

a. Satuan Pendidikan

Kepala sekolah, tenaga pendidik, tenaga kependidikan dan pembina ekstrakurikuler, bersama-sama mewujudkan keunggulan dalam ragam kegiatan ekstrakurikuler sesuai dengan sumber daya yang dimiliki oleh setiap satuan pendidikan.

b. Komite Sekolah

Sebagai mitra sekolah memberikan dukungan, saran, dan control dalam mewujudkan keunggulan ragam kegiatan ekstrakurikuler.

c. Orang tua

Memberikan kepedulian dan komitmen penuh terhadap keberhasilan Kegiatan Ekstrakurikuler.

d. Dinas Pendidikan

Melaksanaan pembinaan, pelayanan, dan pengendalian urusan pemerintah bidang pendidikan terkait pembinaan ekstrakurikuler.

Berdasaarkan Surat Edaran Menteri Pendidikan Nomor 15 Tahun 2020 tentang Pedoman Penyelenggaraan Belajar Dari Rumah Dalam Masa Darurat Penyebaran Covid-19, maka seluruh pelaksanaan kegiataan akademik di sekolah dilakukan secara daring dari rumah masing-masing. Meskipun dalam kondisi belajar di rumah, tetapi bukan berarti kegiatan ekstrakurikuler tidak dapat dilaksanakan. Peserta didik diharapkan tetap melaksanakaan proses pembelajaran dan latihan untuk tetap mencapai tujuan yang telah ditetapkan. Hal tersebut bisa disiasati dengan mempersiapkan hal-hal sebagai berikut:

a. Tim pembina/pelatih membuat program pembelajaran dan latihan untuk dapat dilaksanakan oleh masing-masing peserta didik yang ditugaskan kepada di rumah.

b. Program pembelajaran dapat berisikan materi latihan sesuai kebutuhan bidang masing-masing ekstrakurikuler.

c. Selain unsur pengembangan, nilai-nilai yang ada pada pengembangan pendidikan 
karakter menjadi materi inti dari setiap program ekstrakurikuler.

d. Program pembelajaran dan latihan dapat dibuat dalam bentuk modul atau kertas kerja, video, dan lain-lain.

e. Tim pembina/pelatih memastikan program yang dibuat dilaksanakan secara baik oleh peserta didik dengan melakukan evaluasi melibatkan orang tua.

Tahap ketiga dari implementasi ekstra kurikuler di sekolah/madrasah adalah evaaluasi. Evaluasi program kegiatan ekstrakurikuler dimaksudkan untuk mengumpulkan data atau informasi mengenai tingkat keberhasilan yang dicapai peserta didik. Penilaian dapat dilakukan sewaktu-waktu untuk menetapkan tingkat keberhasilan peserta didik pada tahap-tahap tertentu dan untuk jangka waktu tertentu berkenaan dengan proses dan hasil kegiatan ekstrakurikuler. Penilaian program ekstrakurikuler menekankan pada penilaian tes tindakan yang dapat mengungkapkan tingkat unjuk perilaku belajar kerja peserta didik. Penetapan tingkat keberhasilan untuk program ekstrakurikuler didasarkan atas standar minimal tingkat penguasaan kemampuan yang disyaratkan dan bersifat individual. Sekolah hendaknya membuat laporan, baik laporan untuk keseluruhan program kegiatan ekstrakurikuler dan untuk setiap jenis kegiatan ekstrakurikuler ataupun pertanggungjawab keuangan yang telah dialokasikan digunakan untuk kegiatan yang dimaksudkan.

\section{KESIMPULAN}

Dari paparan di atas dapat disimpulkan bahwa ekstra kurikuler merupakan kegiatan di luar jam belajar yang bertujuan untuk mengembangkan potensi, bakat, minat, kemampuan, kepribadian, kerjasama, dan kemandirian peserta didik secara optimal dalam rangka mendukung pencapaian tujuan pendidikan nasional. Kegiatan ekstrakurikuler termasuk di dalam rencana kerja tahunan satuan pendidikan, dan kegiatan ekstrakurikuler perlu dievaluasi pelaksanaannya setiap semester oleh satuan pendidikan. Dalam implementasinya di sekolah/madrasah meliputi tiga tahapan yaitu perencanaan, pelaksanaan dan evaluasi.

\section{DAFTAR PUSTAKA}

A.M. Sudirman. (2001). Interaksi dan Motivasi Belajar Mengajar, Jakarta: PT. Raja Grafindo Persada.

Dewi, Anita. 2019. Manajemen Pendidikan Elaborasi Peningkatan Mutu. Yogyakarta: K-Media.

Latifah, L., Ngalimun, N., Andi Setiawan, M., \& Haji Harun, M. (2020). Kecakapan Behavioral Dalam Proses Pembelajaran PAI Melalui Komunikasi Interpersonal. Bitnet: Jurnal Pendidikan Teknologi Informasi, 5(2), 36-42. https://doi.org/10.33084/bitnet.v5i2.1747

Muhaimin, dkk. (2009). Manajemen Pendidikan Aplikasinya Dalam Penyusunan Rencana Pengembangan Sekolah/Madrasah. Jakarta: Kencana Prenada Media Group

Peraturan Pemerintah Nomor 19 Tahun 2005 tentang Standar Nasional Pendidikan

Peraturan Pemerintah Nomor 32 Tahun 2013 tentang Perubahan atas Peraturan Pemerintah Nomor 19 Tahun 2005 tentang Standar Nasional Pendidikan

Peraturan Menteri Pendidikan dan Kebudayaan Republik Indonesia Nomor 62 Tahun 2014 tentang Kegiatan Ekstrakurikuler pada Pendidikan Dasar dan Pendidikan Menengah

Suryabrata, Sumadi. (1988). Psikologi Kepribadian. Jakarta: PT. Raja Grafindo Persada.

Sarweni. 2020. Implementasi Kebijakan Pendidikan Ekstrakulikuler. Surabaya: Global Aksara Press

Undang-Undang Nomor 20 Tahun 2003 tentang Sistem Pendidikan Nasional 